\title{
Open-ring peripherally enhancing lesion of the cervical spine
}

\begin{abstract}
Figure Sagittal STIR (A) and axial gadolinium enhanced T1-weighted (B) images demonstrate a 3.6-cm expansile lesion of the cervical spine extending from the C2 through C4 level with abnormal STIR signal and associated open-ring peripheral enhancement suggestive of active demyelination
\end{abstract}
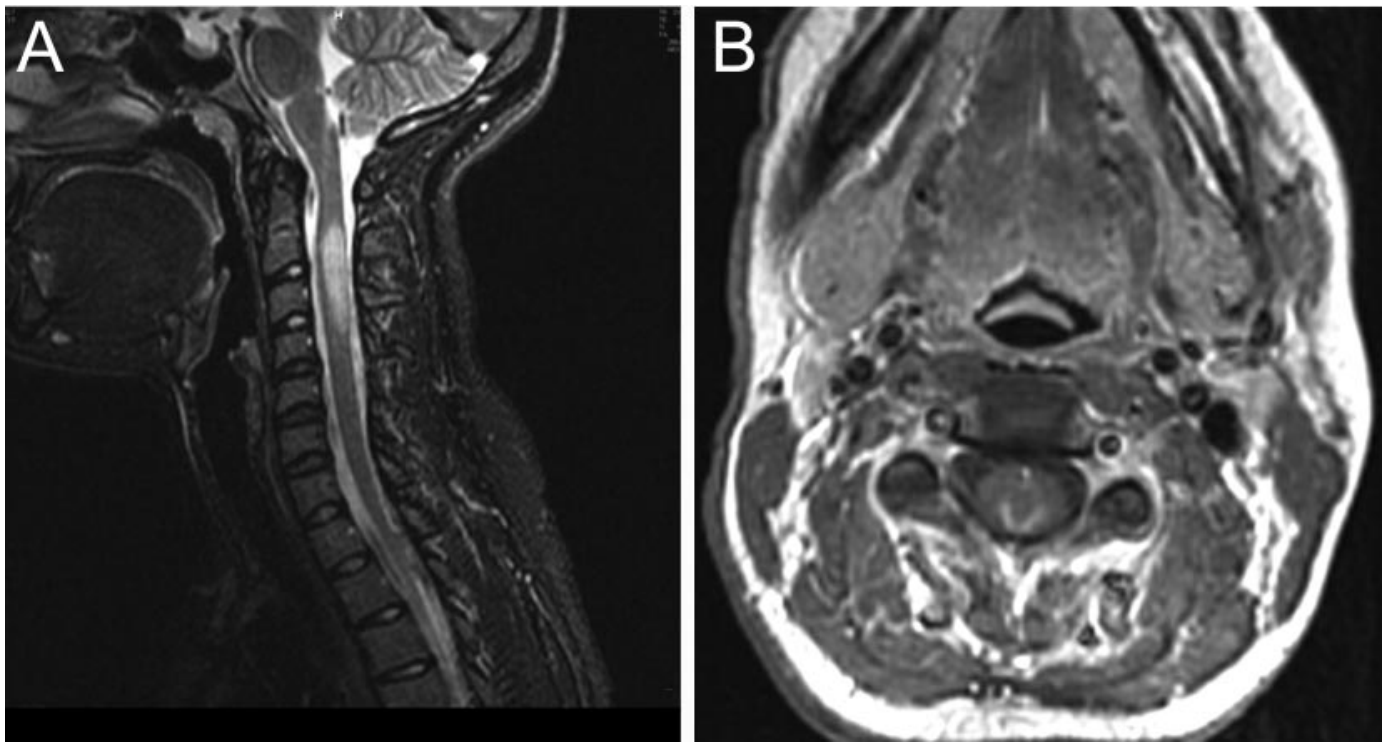

A 26-year-old woman presented with progressive difficulty ambulating and upper and lower extremity numbness. Clinical examination showed dysesthesia and an allodynia sensation in the bilateral upper and lower extremities. She also demonstrated primary dysmetria and incoordination especially on finger to nose testing. Reflexes were extremely brisk and the gait was ataxic and unstable.

CSF analysis revealed increased IgG synthesis rate and oligoclonal banding consistent with multiple sclerosis.

To our knowledge, the association between open-ring peripherally enhancing lesions of the spine (figure) in patients with multiple sclerosis has been previously described only once in the Japanese literature. ${ }^{1}$

Wilson Pyle, MD, Khurshed Dastur, MD, Moshin Rahman, MD, and Jawad Tsay, MD, Pittsburgh, PA

Disclosure: The authors report no disclosures.

Address correspondence and reprint requests to Dr. Wilson Pyle, Department of Radiology, UPMC Mercy Hospital, 1400 Locust St., Pittsburgh, PA 15219; wkpyle@gmail.com

1. Dohi N, Ishikawa S, Kamijyo Y, et al. Multiple sclerosis with open-ring enhancement in the cerebrum and spinal cord. Intern Med 2003;42:273-276. 


\section{Neurology}

\section{Open-ring peripherally enhancing lesion of the cervical spine \\ Wilson Pyle, Khurshed Dastur, Moshin Rahman, et al.}

Neurology 2009;72;381

DOI 10.1212/01.wnl.0000341324.55937.d9

This information is current as of January 26, 2009

\section{Updated Information \& Services}

References

Subspecialty Collections

Permissions \& Licensing

Reprints including high resolution figures, can be found at: http://n.neurology.org/content/72/4/381.full

This article cites 1 articles, 0 of which you can access for free at: http://n.neurology.org/content/72/4/381.full\#ref-list-1

This article, along with others on similar topics, appears in the following collection(s):

All Demyelinating disease (CNS)

http://n.neurology.org/cgi/collection/all_demyelinating_disease_cns MRI

http://n.neurology.org/cgi/collection/mri

Multiple sclerosis

http://n.neurology.org/cgi/collection/multiple_sclerosis

Information about reproducing this article in parts (figures,tables) or in its entirety can be found online at:

http://www.neurology.org/about/about_the_journal\#permissions

Information about ordering reprints can be found online:

http://n.neurology.org/subscribers/advertise

Neurology ${ }^{\circledR}$ is the official journal of the American Academy of Neurology. Published continuously since 1951, it is now a weekly with 48 issues per year. Copyright . All rights reserved. Print ISSN: 0028-3878. Online ISSN: 1526-632X.

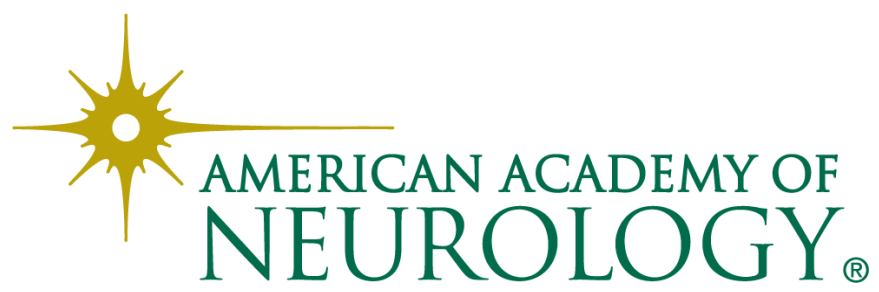

